\title{
A Biological Note on Bledius salsus MiYATAKe (Coleoptera, Staphylinidae), the Species of Insect Most Injurious to the Clay-bed in Sloping Salt-fields
}

\author{
By Hiroshi Matsuzawa
}

Laboratory of Applied Entomology, Faculty of Agriculture, Kagawa University, Miki-cho, Kagawa

Recently, Miyatake (1963) published a paper on a new species of Staphylinid beetle from Shikoku, Japan, assigning it the name: Bledius salsus. This Staphylinid beetle is the most injurious insect to the clay-bed (about $9 \sim 10 \mathrm{~cm}$ in thickness with $1 / 120 \sim 1 / 150$ of slope) in the sloping saltfields of Japan, although several other harmful insect species are also found there.
The beetle lives in colonies burrowing galleries into the clay-bed onto which salt water is flooded continuously in order to increase the salt concentration by evaporation. The enormous number of galleries found in the clay-bed results in heavy loss of the salt water during the process of concentration. In addition, the surface condition on which gravel is spread is

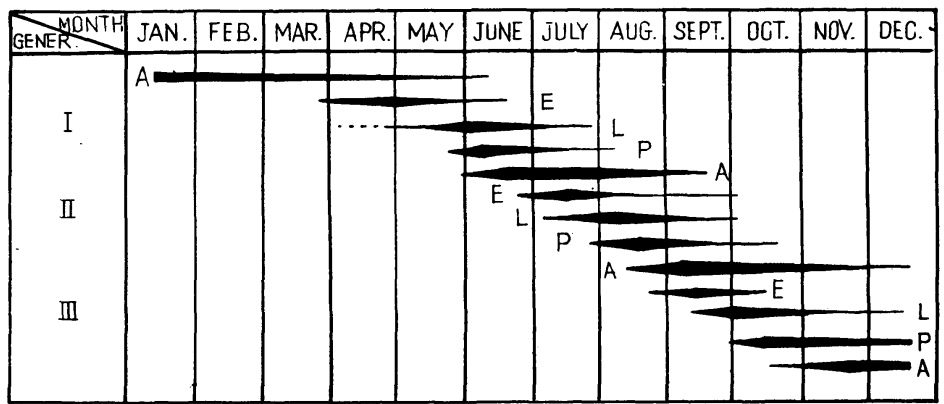

Fig. 1. Life history chart of Bledius salsus in Kagawa. A : Adult, E : Egg, L : Larva, P : Pupa

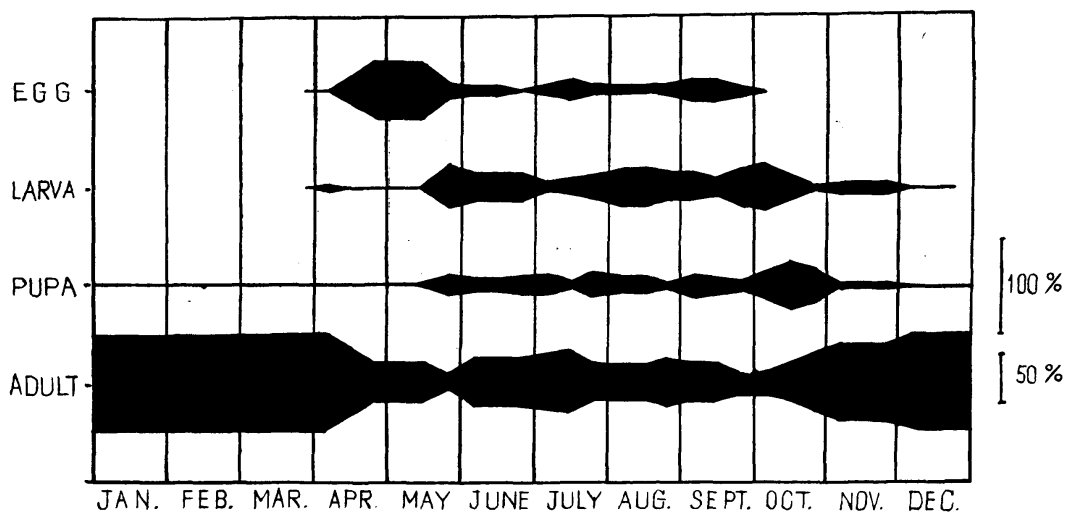

Fig. 2. Seasonal variation in percentage of individuals of each stage of Bledius salsus.

1 Contribution No. 68 from the Laboratory of Applied Entomology, Faculty of Agriculture, Kagawa University.

(Received for publication, February 25, 1964) 
disrupted, considerably reducing the concentration efficiency of the bed.

Because of the great economic importance of Bledius salsus, as well as its peculiar habits, the present study was carried out.

\section{OBSERVATIONS}

Life cycle: This species of Staphylinid beetle seems to have three generations a year, overwintering in the adult stage, though a few individuals overwintered in the pupal stage. The first egg laying period of the adult female begins in midApril and lasts until the end of May or the beginning of June. The second period of egg laying is from the latter part of June to the middle or end of July, and the third period is from the latter part of August to the end of September. In general, the second and third periods of egg laying are not so clearly discernible as the first period. A small number of individuals appears to have four generations a year.

The life history chart is given in Fig. 1. The seasonal variation of the percentage of individuals of each stage based on census is given in Fig. 2. Because of the difficulty of conducting an actual census throughout a year, the actual state of the population growth of the beetle in fields can not be shown here, whereas the number of adults seems to increase remarkably

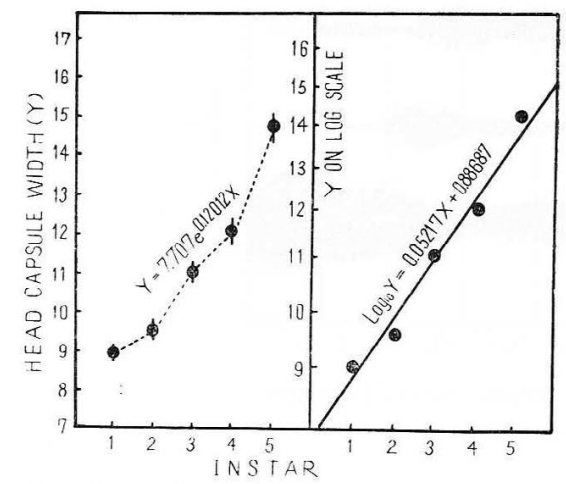

Fig. 3. Growth of the head capsule width of the larve of Bledius salsus.

1 unit $(\mathrm{Y})=0.083 \mathrm{~mm}$ during the season from early summer to early autumn, with the greatest increase in summer.

Development: The developmental period is $14 \sim 20$ days for the egg, 40 50 days for the larva, $2 \sim 4$ days for the prepupa and $6 \sim 8$ days for the pupa, under natural conditions; the developmental durations being the shortest in mid-summer. The total duration of the developmental period from the egg to the adult stage is about 70 days on an average.

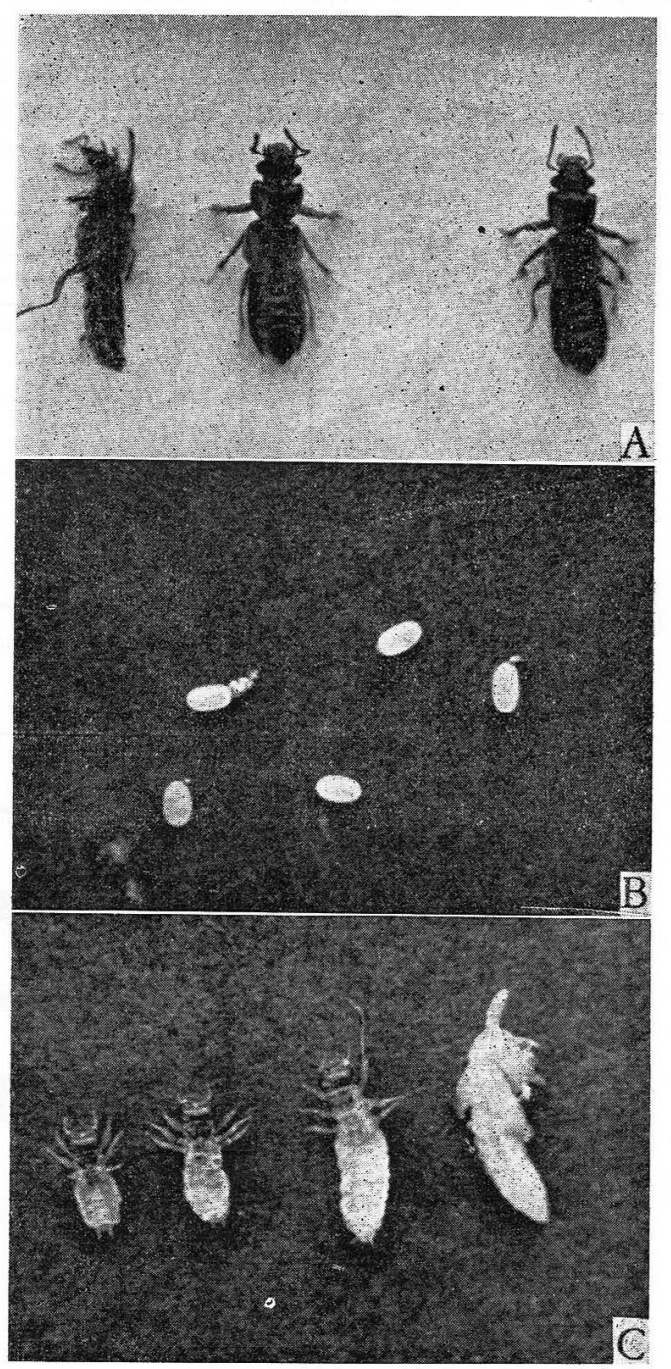

Fig. 4. Four stages of Bledius salsus. A : Adult ( $\hat{o}$, 우), B : Egg, C : Larva \& pupa $(\hat{s})$ 
The beetle has five instars in its larval stage. The increase in the head capsule width is given in Fig. 3. It appears that DYAR's formula for growth of the head capsule, $\log Y=a+b X$, is closely applicable to the species. All the stages of the beetle are given in Fig. 4.

Life span of the adult beetle and the number of eggs laid per adult female: The length of life of the adult beetle varies with the season, but is relatively long, particularly in winter at which time the adults might live $2 \sim 4$ months or more. The life span of the adult during the warm season is shorter than in winter being about $20 \sim 40$ days in both sexes.

The number of eggs laid per adult female is rather small, usually only 5 10 eggs at a time. The eggs are laid separately in specially prepared small cavities in the walls of the breeding chamber (Fig. 5). The egg cavities seem to be made at respective times of the egg laying, and are not elaborate. Egg laying takes place two or three times during the life of the female.

General habits and the damage to the clay-bed in the sloping salt-field: The adult is entirely nocturnal. Most of the activities such as flying, creeping and making galleries in the clay-bed surface take place only at night. They fly actively at night, and display a highly positive phototaxis, particularly to a fluorescent lamp during the warm season. It is not unusual, by using a blue fluorescent lamp (FL-20BL) and a trap, to capture as many 5,000 individuals in one night. Over 10,000 beetles have been captured occasionally.

The various types of galleries formed in the clay-bed, and their frequency of occurrence is given in Fig. 6. In general, the galleries of type A or B occur more frequently than the other types. The gallery of type $F$, which resembles the mother cell of some Scolytid beetles, is characteristic in its construction with breeding rooms in which only a pair of adults is found. Although the copulation of the adults is not observed, copula-

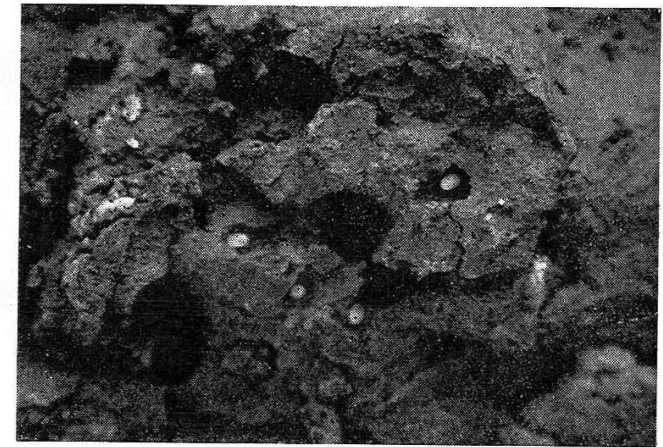

Fig. 5. Eggs deposited on the clay-bed.

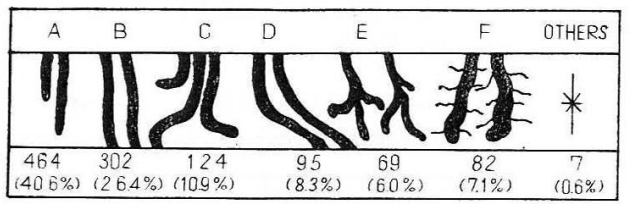

Fig. 6. Types of galleries formed on the clay-bed.

tion and egg laying probably take place in the characteristic breeding room in the gallery (type F). Young larvae are also found in galleries with rooms of this type. On the other hand, only a male or female is usually found in galleries of the other types.

The larvae live only in galleries in the clay-bed and never go out onto the surface of the bed. When the larvae are ready to pupate, they prepare an oval pupation cell in the wall or at the end of the galleries, where they prepupate. The newly emerged adult can not fly immediately as the cuticle is still quite soft. After continuous observation, it was ascertained that $7 \sim 10$ days are needed for the newly emerged beetle to reach the normal adult state.

The food habits of the adults and the larvae are not clear. It is certain, however, that they do not eat the dead bodies of small animals or other decayed matter. From several reasons, the clay particles of the bed contain abundant organic matter and this seems to be somehow utilized as their food.

The cause and effect relationship in regard to damage of the clay-bed by Bledius salsus is summarized as follows: 


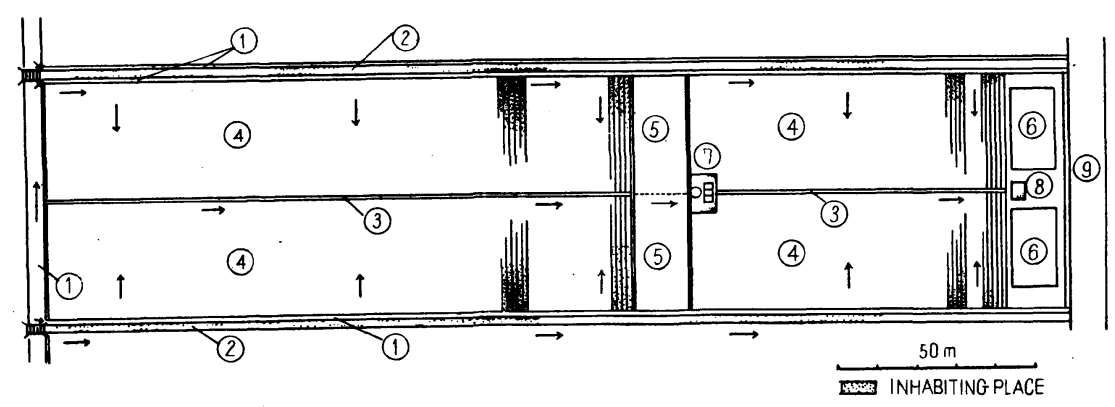

Fig. 7. Inhabited location of Bledius salsus in the salt-field. 1: Trough for supplying sea-water. 2: Path. 3: Trough for gathering concentrated sea-water. 4: Clay-bed. 5,6: Shijōka equipment (Bamboo evaporation tower). 7,8: Pump and tank. 9: Bank.

\section{DAMAGED CLAY-BED}

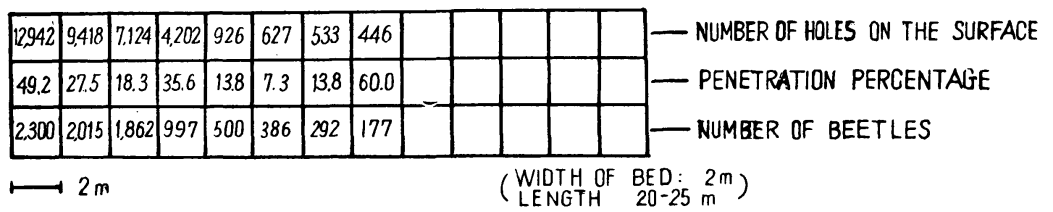

Fig. 8. State of inhabitation of the beetle, distribution of the galleries and the percentage rate of penetration of the galleries down to the bottom of the bed.

Table 1. Frequency distribution of the holes (the entrance of gallery) of various size on the surface of the clay-bed.

\begin{tabular}{|c|c|c|c|c|c|c|c|c|c|c|c|c|}
\hline Diameter $(\mathrm{mm})$ & 1.0 & $\begin{array}{l}1.1 \sim \\
2.0\end{array}$ & $\begin{array}{c}2.1 \sim \\
3.0\end{array}$ & $\begin{array}{c}3.1 \sim \\
4.0\end{array}$ & $\begin{array}{l}4.1 \sim \\
5.0\end{array}$ & $\begin{array}{c}5.1 \sim \\
6.0\end{array}$ & $\begin{array}{c}6.1 \sim \\
7.0\end{array}$ & $\begin{array}{l}7.1 \sim \\
8.0\end{array}$ & $\begin{array}{c}8.1 \sim \\
9.0\end{array}$ & $\begin{array}{l}9.1 \sim \\
10.0\end{array}$ & $10.0<$ & Total \\
\hline $\begin{array}{c}\text { Number of } \\
\text { holes observed }\end{array}$ & 30 & 787 & 1,088 & 272 & 335 & 211 & 90 & 30 & 90 & 90 & 0 & 3,023 \\
\hline
\end{tabular}

\section{Cause}

A. Destruction of the surface condition of the bed.

B. Destruction of the clay-bed proper.

\section{Effect}

A. Reduction of concentrating efficiency.

$B$. Heavy loss of salt-water by leakage.

During all stages of its development, Bledius salsus inhabits the clay-bed of the salt-field and burrows numerous galleries. The galleries are especially numerous in area of the field nearest the sea-water supply trough (Fig. 7). Galleries are also found in the paths between the fields, in the clay near the sea-water supply pipes, around the salt-water tank, around the pump shed, and in the clay reserve dump.
The area where the beetle lives is limited to the elevated portion of slight slope equivalent to $1 / 3 \sim 2 / 3$ of the clay-bed area (about $20 \sim 25 \mathrm{~m}$ in length). The lower parts of the clay-bed are seldom found to be inhabited. The state of inhabitation, the distribution of the galleries and the percentage rate of penetrating down to the bottom of the bed are given in Fig. 8 .

It is evident that the damage of the clay-bed is indeed very great. In the "Setouchi" district of Japan, the damage of the sloping salt-field by the beetle is a very serious problem. Frequency of the holes (the entrance of gallery) of various sizes on the surface of the clay-bed is given in Table 1. 


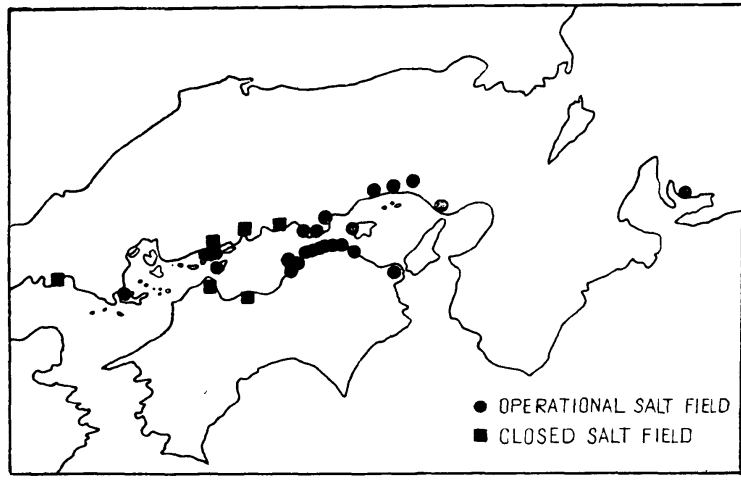

Fig. 9. Distribution of Bledius salsus in Japan.

Distribution: Bledius salsus distributes widely along the cost of the inland-sea in Japan, and is found in almost all saltfields, including the so-called "Irihama salt-fields" of the old system no longer in use. (Fig. 9).

Although the original habitation of Bledius salsus has not been determined, it is likely that the beetle inhabits those coastal regions abundant in clay.

\section{GENERAL CONSIDERATIONS}

Bledius salsus is one of the most injurious species of insects in the sloping salt-fields of Japan. According to investigations done by the Takamatsu Regional Bureau of the Japan Monopoly Corporation, annual losses in salt production due to the beetle are estimated to be from 10,000 to 50,000 yen per hectare. This estimate is based upon actual measurement of loss of salt-water through leakage and practical survey on the inefficiency of concentration due to surface damage. The actual losses, however, may be greater than estimated one because of the large number of damaged salt-fields which are lying idle or made unusable. Since the damage is gradually increasing in all the salt-fields throughout Japan, it is imperative to establish how to control them.

From the entomological point of view, it is unquestionable that the inhabitation of the beetle depends entirely upon the clay-bed in the sloping salt-field. As the information about the general habits, life cycle, developmental period, fecundity, longevity, distribution and inhabitation in the clay-bed accumulates, certain measures for the control of Bledius salsus will be introduced in the near future.

\section{SUMMARY}

Biology of Bledius salsus Miyatake, the most injurious species of insect in the clay-bed of the sloping salt-fields of Japan, was investigated.

1. This species of Staphylinid beetle usually has three generations a year, whereas a small number of individuals appears to have four generations. Overwintering is done in the adult stage with exceptional individuals hibernating in the pupal stage.

2. There are three egg laying periods as follow: the first period lasts from midApril to the end of May or the beginning of June, the second period from the latter part of June to the middle or end of July, and the third period from the latter part of August to the latter part of September.

3. The developmental stages are: egg 14 $\sim 20$ days, larva $40 \sim 50$ days, prepupa $2 \sim 4$ days and pupa $6 \sim 8$ days under natural conditions.

4. Five instars are observed in the larval stage.

5. Length of the life for the adults of both sexes is $20 \sim 40$ days during the warm season and $2 \sim 4$ months or more in winter.

6. Egg laying seems to take place two to three times during the life of the female, only 5 10 eggs each.

7. Most of the activities of the adult, such as flying, creeping, burrowing galleries in the clay-bed etc. take place at night. The beetles show a marked positive phototaxis, especially to a fluorescent lamp.

8. The copulation probably takes place in a characteristic breeding room of the gallery which is relatively larger than other chambers. Egg laying might also take place in these rooms.

9. The feeding habits of the adult and larvae have not been clearly determined, 
but abundant organic matter in the clay particles of the bed may be utilized as food.

10. All the developmental stages inhabited in the salt-fields particularly in the clay-bed near the sea-water supply.

11. Distribution of Bledius salsus is wide and cover all the existing salt-fields in Japan.

12. Damage of the clay-bed is due to the destruction of the surface conditions, and the clay-bed proper. This results in reduction of the salt-water concentrating efficiency, and leakage of the salt-water through the clay-bed.

\section{ACKNOWLEDGEMENTS}

The author wishes to express his hearty thanks to the Japan Monopoly Corporation for the support of a Grant in Aid for the Special Scientific Research on salt manu- facturing. Many grateful thanks are also due to Prof. M. CHŪıo of Kagawa University, Prof. T. ADAchi of Tōyō University, Mr. M. Miyatake of Ehime University, Dr. T. TAKAoka of the Tobacco Experiment Station of the Japan Monopoly Corporation, for their valuable suggestions and encouragement during the course of this work. Thanks are also due to the staffmembers of the Takamatsu Regional Bureau of the Japan Monopoly Corporation, the Kagawa Salter's Prefectural Association, the Fuso Salter's Association and the Tamamatsu Salter's Association, for their kind help in many ways during the work.

\section{REFERENCE}

Miyatake, M. (1963) Trans. Shikoku Ent. Soc. 7: $106 \sim 110$.

流下式塩田の害虫オオツノ八ネカクシの生態に関与る知見

松沢寞

香川大学農学部応用昆虫学研究室

現行流下式塩田の流下盤内に無数の坑道を作って生息 するオオツノ八ネカクシの䓕大なる虫害は, 本邦製塩業 上大きな問題となっているが，1963 年秋以来 1 年余り の間, 本種の生態について調查研究を行なった結果, 1 年 3 回（時に一部は 4 回）の発生をなし，一部はさな き，大部分は成虫にて越冬することがわかった。産卵期 は大まかには， 4 月中旬〜 5 月下旬ないし 6 月上旬， 6 月下旬〜 7 月中下旬, 8 月下旬〜 9 月下旬の 3 期で，ま たその発育所要日数は, 卵 14〜20 日, 幼虫 40〜50日, 前蛹 $2 \sim 4$ 日, さなぎ $6 \sim 8$ 日であった。幼虫は 5 令 の令期をもつようで, 卵から成虫までは, 普通 70 日内 外であった。成虫の生存日数は, 越冬期は 2〜 4 月また はそれ以上にもわたるが，活動期には概して 20〜40 日
ぐらいであった。

また産卵は 1 粒ずつ坑道の壁の小孔中になされるが, $5 \sim 10$ 卵ずつ $2 \sim 3$ 回産卵されるもののごとく思われ た。流下盤での生息は, 給水樋に近い, 盤長の大体 $1 / 3$ 〜2/3 にあたる部分で, 無数に作られた坑道は, 垂直的 なものがもっとも多く，盤底までの貫通率もかなり高か った。

成虫の青色䖝光灯への飛来沙常に顕著で, この方法 は，本種防除の 1 策となりうると思われた。

本種の分布は, 調査の結果, 愛知県以西の現行流下式 塩田には例外なく分布することが明らかとなり，また旧 入浜式塩田跡にも，ほとんどすべて生息するようであっ た。 